\title{
Impacting the B2B-Business Development Process: Social Media Usage within a Global Software Environment
}

\author{
Werner Krings $P h D$ \\ Adjunct Professor \\ Framingham State University,USA \\ E-mail:wkrings@framingham.edu
}

\begin{abstract}
The thesis aims to explore and explain how Social Media impacts the B2B-Business Development process in a global software environment. Mixed-methods uncover the leading media platforms applied in the Business Development process cycle. The thesis produced a model, illustrating two dimensions of Social Media Business Usage, four critical Business Development process phases, and their impact on Performance mediated by Social Capital. To extend generalizability, future research may focus on testing the model for New Business Development exclusively. Significant contributions are classifying relevant Social Media platforms, distilling the process phases with the greatest impact on performance. The creation of new indices advances the performance discussion, and the typology of Business Developers capitalises on optimising the process sequence.
\end{abstract}

Keywords: B2B, Business Development Process, Social Media, Global Software Environment.

\section{Introduction}

This thesis presents a novel conceptualization of B2B-Business Development that reflects on Social Media and Traditional Media Usage during different B2B-Business Development process phases. The aim is to expand the understanding whether B2BBusiness Development can be rendered more agile and accelerated with measurable performance.

Recent academic and practitioner studies presume that Social Media Usage in B2B-Business Development is an emerging phenomenon with little direction and scant guidance (Michaelidou et al., 20II). The paucity of scholarly research in the past decade can be mainly explained by the uncertain effects of Social Media Usage on Performance, the absence of a clear definition of B2B-Business Development (Eidhoff \& Poelzl, 20I4) and the isolated research of both areas with the consequence that the adoption of Social Media is delayed in Business Development (Moore et al., 2015).

B2B-challenges like the uncertain global economy, growing competition and the availability of new technologies urge companies to review existing processes and activities to generate new business faster and mitigate the risk of losing their competitive edge. Thereby, individuals and organisations should be selective about Social Media. Categorizing and understanding the platforms affecting performance-critical Business Development process phases is essential.

Possible applications for this research are closing scholarly gaps with implications for practitioners. Firstly, to enrich traditional activities, in Business Development e.g., cold-calling (Brown, 201 I). Secondly, to abbreviate the duration of Business Development and Sales process cycles with a media mix (Davis \& Sun, 2006). Thirdly, to streamline the lengths of both processes (Avlonitis \& Panagopoulos, 2010). Fourthly, to improve Performance via Social Capital and Usage Criteria (Rauniar et al., 2014). Fifthly, to understand how buyers evaluate social media efforts of vendors (Ramos \& Young, 2009). Finally, to recognize intergenerational differences overlooked by Business Development scholars in conjunction with digitalization (Royle \& Laing, 20I4).

The starting point is to discover the prevailing concepts and theories shown in Table I. By drawing on an interdisciplinary perspective, I developed a framework that sheds light on critical Social Media platforms in B2B-Business Development within a global software context.

Scholars do not signal what constitutes operative Business Development. Thus, I considered it essential to examine possible phases derived from similar processes in B2B-Relationship Marketing and Sales. This approach is justifiable from the liaison role of B2B-Business Development.

Based on empirical findings, I argued that this organizational construct comprises four process phases conceptualizing the behavioral outcome of Performance. I refined the framework by comparing the central themes in the literature with job descriptions, testimonies, and best practices from twelve semi-structured interviews warranting theme saturation.

Mixed methods addressed the overarching research question and sub-questions influential in extending the geographical scope of the study, and merging vendors, third-parties, and buvers. 
How does Social Media Usage impact B2B-Business Development and ultimately contribute to Performance within a global software environment?

RQI. What are relevant platforms and process phases?

RQ2. What characteristics moderate or mediate the relationship between the Business Development process and Performance?

RQ3. Does Social Media Business Usage accelerate the B2B-Business Development Process?

RQ4. Which managerial strategies and guidelines have emerged?

Table I. Framework (Insert in Appendix)

\section{Conceptual Framework}

Regular Social Media features like cost-advantages, interactivity, the velocity of information, 24-7 availability and immediacy (Katona \& Sarvary, 20I4, p. I44) cast doubt on traditional media usage.

Scholars are divided on whether completely replacing traditional media or combining both media (Stephen \& Galak, 2012). Kaplan \& Haenlein (20I0,6I)'s definition "Social Media is a group of Internet-based applications that build on the ideological and technological foundations of Web 2.0, and that allow the creation and exchange of User Generated Content" recommends specific platforms for B2B-Business Development.

Opponents of Social Media fear distraction and distress through information overflow. Proponents argue that participating in networks boosts relationships through communication, collaboration, gathering and sharing information (McCorkindale et al., 2013).

The table below contains managerial guidelines to leverage disruptive-innovative Social Media technologies in B2BBusiness Development.

Table 2. Social Media in B2B-Business Development (Insert in Appendix)

As such, the number and type of platforms determine the Social Media approach.

Restricting the number of platforms is essential for parsimony reasons and from a strategic B2B-marketing aspect: 80\% of Fortune 500 companies apply Social Media of which 55\% use three to five platforms (Taken Smith et al., 2015, p. I35).

Brennan \& Croft (2012, p. I06) noticed that leading software companies in the UK most frequently utilize LinkedIn, Twitter, Facebook, and Blogging - platforms relevant to B2B-Business Development. Agnihotri et al., (2012) regard social networking sites as essential for prospecting and networking whereas the purpose of (micro-) blogs lies in producing digital content, staying in touch with customers, and identifying business requirements of potential buyers. LinkedIn provides access to decision-makers while Twitter spots opportunities (Itani et al., 2017).

O’Leary (20II) advocates prohibiting personal platforms, e.g., Facebook, YouTube for productivity or security risk reasons. Though I initially agreed with this opinion, I refuted banishing personal platforms because:

- Professional and Social Networking Sites are converging regarding business/personal content design.

- The emphasis on specific business/personal platforms varies within different generations and industries.

\section{Methodology}

Because of the empirical and theoretical orientation of the core concepts (Table I), the combination of formerly separate research areas suggests mixed-methods (Alves et al., 2016). This approach seems reasonable in light of the generalization of research findings.

I became aware that Social Media in the global software industry has to be understood and conceptualized from the dominant perspectives of Information Technology, Business Development, Marketing, and Sales to retrieve of the myriad of available platforms the set optimally resonating with the individual phase or the entire process cycle.

This implies that raising awareness of the Business Development process-orientation comes first. As I showed before, the phases follow similar process activities of the related functions of B2B-Business Development.

However, this research goes beyond replicating common processes of both functions. It signifies an insightful shift from buzzwords towards a comprehensive definition of B2B-Business Development contributing to new knowledge. I accomplished this by emphasizing the unique liaison-role which is ignored by practitioners and scholars. 
Thus, B2B-Business Development becomes the focal point aligning the siloed functions, Marketing, and Sales, being responsible for building lasting relationships guided by principles of commitment, trust, and collaboration with the objective of co-creating value-oriented solutions.

The development and discussion of the initial model (Figure I) have to be understood from the background of the concepts and themes recognized in peer-reviewed journals, job descriptions of software companies, and results of the pilot study.

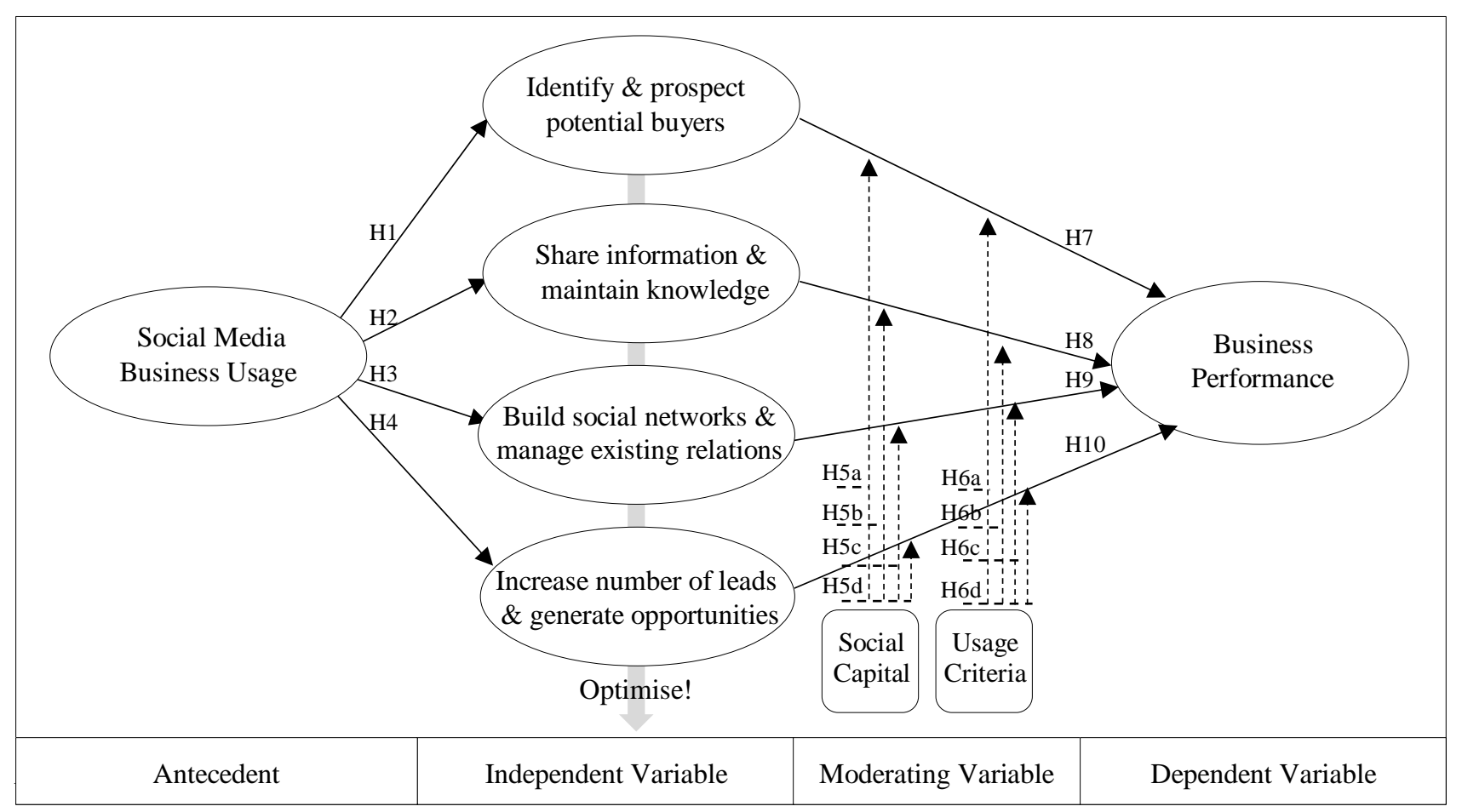

Figure I. Conceptual Model

$\mathrm{H}_{\mathrm{I}+}-\mathrm{H}_{4+}$ : Social Media Business Usage has a positive relationship on the four B2B- Business Development Process Phases.

The first process phase consists of discovering and screening the right buyer decision-makers. B2B-Business Developers are responsible for building awareness with prospective key contacts in complex software purchase decisions. Thereby, Social Media replaces obsolete Rolodexes to research and retrieve detailed prospect information (Rodriguez et al., 20I2). From my viewpoint, Social Media defuses disruptive cold calls by meaningful conversations with a right balance between privacy and selfdisclosure based on profile information.

The second process phase involves the exchange of transaction relevant product/service information with prospective buyers and upholding business domain knowledge. This consists of competitor knowledge to differentiate and tailor the offered solution, as well as, tacit knowledge to ensure a best possible buyer-vendor fit. In this context, scholars especially mention the information quality with its dimensions accessibility, believability, completeness, timeliness, and comprehensiveness (Lee et al., 2002, p. 139). In contrast, practitioners viewed the second phase as an extension of the first one by mentioning activities like building rapport, trust, educating and listening. Thus, profile information and content should be customer-oriented and regularly updated.

Therefore, it is expected that Social Media tools quicken and simplify the reciprocate communication-information and knowledge exchange by rendering this phase more agile while ensuring higher quality.

The third process phase consists of extending networks with current and potential customers and managing relationships. Rodriguez et al., (2014) recognized that customer-oriented technology is critical in building business networks, for strengthening B2B-relationships and enhancing processes and performance. The definition of this process phase comes close to the description of the practitioner experiences. By establishing authentic, engaging, and trustworthy relationships, I consider this phase to be especially crucial for the B2B-Business Development process because of its impact on subsequent sales processes. 
The fourth process phase describes the individual and functional performance in conformity with the entrepreneurial business process of discovering, evaluating and exploiting opportunities (Eckhardt \& Shane, 2003). In the software industry, B2B-Business Developers differentiate between leads, i.e., key contacts belonging to the buying center and opportunities, i.e., emerging software projects in the near future. Social Media is instrumental in spotting new opportunities (Jussila et al., 20I4, p. 606) with LinkedIn as the leading social platform for generating B2B-leads (80.33\%) versus Twitter (I2.73\%) (Colwyn, 2014). It takes six to eight touch-points to complete a profitable opportunity (Glynn, 20I5). This phase is supported by peerreviewed journals and pilot study. Thus, Social Media technology might increase the lead quality and closing rate of opportunities.

$\mathrm{H}_{5 \mathrm{a}}+-\mathrm{H}_{5 \mathrm{~d}+}$ : Social Capital positively moderates/mediates the relationship between the Social Media Business Usage affected B2B-Business Development process and Business Performance.

Social Capital might translate in economic advantages by utilizing existing contacts to target decision-makers with benefits like "facilitating access to a broader source of information and improving information's quality, relevance, and timeliness" to "influence, power, and control", expedite prospecting, and "solidarity" (i.e., shared norms, trust, and commitment), simplifying the relationship-building (Adler \& Kwon, 2002,21;29). Moreover, these hypotheses address whether it is sustainable that Social Capital optimizes knowledge sharing processes or gains relevant insights because of personal contacts (Engelen et al., 2016). Thus, Social Capital might act as moderator or mediator variable.

$\mathrm{H}_{6 a+}-\mathrm{H}_{6 \mathrm{~d}+}$ : Usage Criteria positively moderate/mediate the relationship between the Social Media Business Usage affected B2B-Business Development process and Business Performance.

Usage Criteria like career level, technical savviness, perceived playfulness, perceived ease of use, usefulness, and usage intensity might take a moderator or mediator role. For example, younger B2B-Business Developers expose different attitudes and behaviors compared to their more established peers. Keinänen et al., (2015, pp. 717,718) notice that Social Media engagement is inversely proportional with seniority level while Moore et al., (2015, p. 6) highlight differences in usage intensity between managers and staff. Furthermore, technophobia/-philia, resistance/acceptance might influence Social Media Usage behavior. Therefore, it is expected that Usage Criteria affect performance by optimizing underlying processes.

$\mathrm{H}_{7+}-\mathrm{H}_{10+}$ : There is a positive relationship between the Social Media Business Usage affected B2B-Business Development process and Business Performance.

The influence of Social Media within different phases of the B2B-Business Development cycle on Business Performance is mostly supported by M. Schultz et al., (2013).

Identifying and prospecting buyers with direct responsibility for software purchases through Social Media renders B2BBusiness Development processes more agile and closes business deals faster. This observation is also accurate when firm-/market specific knowledge supports in developing innovative software solutions, deepening the relationship with buyers and increasing leads and opportunities. All these aspects positively might influence the conversion rate in new business (Pöyry et al., 2017).

\section{Discussion}

The pre-test with ten executives in Business Development, Marketing, and Sales of various verticals in Europe and the US refined the content and scales of the provisional questionnaire and ensured a high response rate as a quality characteristic of the Qualtrics $@$ survey.

The core concepts were condensed with factor analyses (IBM SPSS/AMOS v23) yielding two dimensions for Social Media Business Usage.

Table 3. Measurement Scales (Antecedent) (Insert in Appendix)

The quantitative research results indicated that the theoretical assumptions had been essentially confirmed. Nevertheless, Usage Criteria neither acted as moderator nor mediator, for lack of statistical significance. Conversely, Social Capital displayed a positive indirect mediator effect.

The finalized Structural Equation Model as shown hereafter largely supported the conceptual model (Figure I). The Goodness-of-Fit Statistics were only acceptable for 243 of 530 respondents, namely High-Social-Media-Low-TraditionalMedia-Users and therefore represented a significant limitation. 


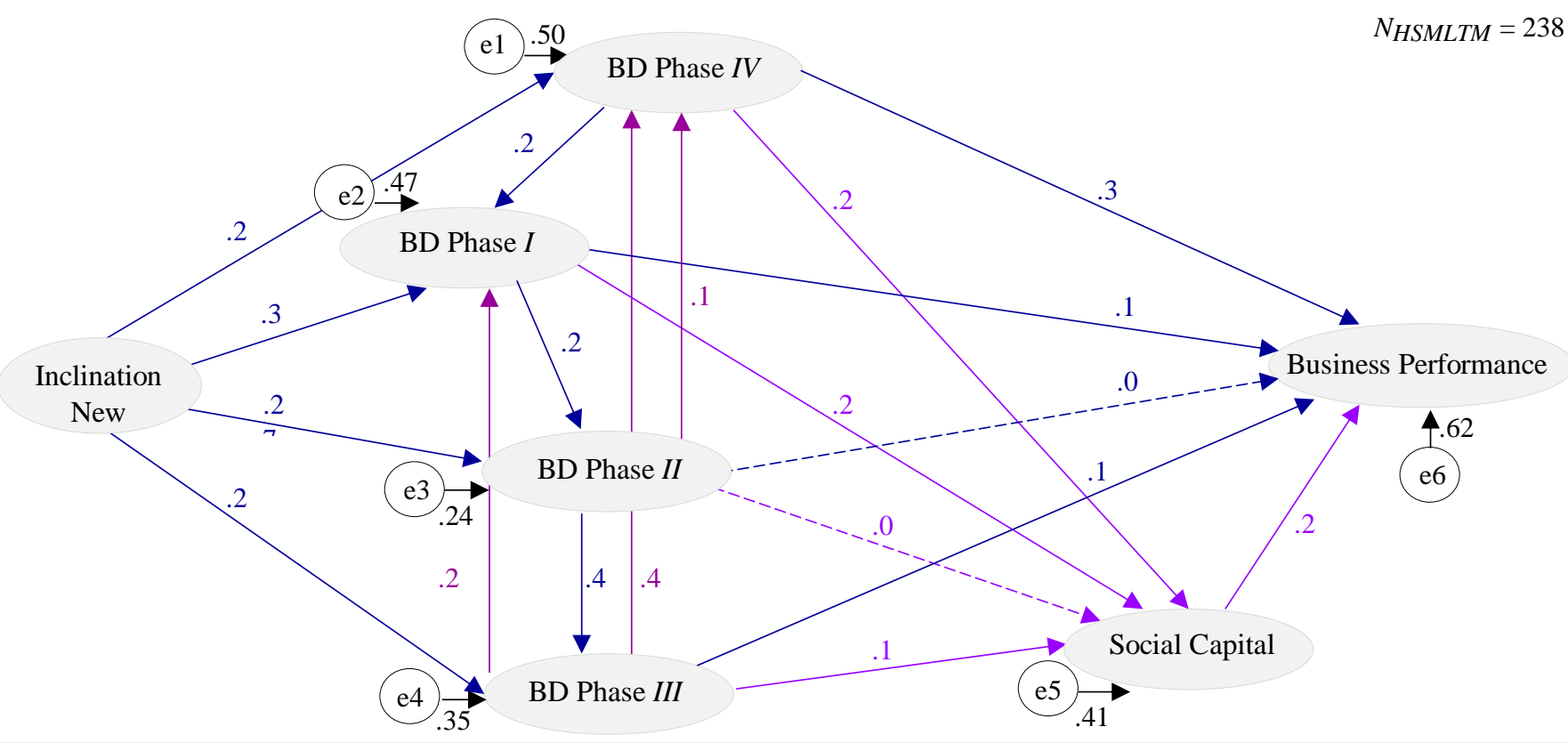

The grey coloured ellipses represent the model variables. The plum coloured arrows reflect the incorporated relationships based on the Modification Indices Analysis. The blue coloured arrows show the direct effects while the purple coloured arrows demonstrate the indirect effects via Social Capital. The dotted lines indicate non-significant path values $(p>.05)$.

Figure 2. Finalized Structural Equation Model

The research questions that initially guided my thesis could be answered. Despite concerns, that mostly junior executives would embark on this journey some results surprised.

A considerable number of C-Level/Senior Management respondents (50.6\%) indicated that the subject is taken seriously on board-level. In contrast, the average age ( 46.8 years) is in line with (Keinänen et al., 20I5).

Academically, substantial contributions were achieved.

The hypotheses of the original model were largely upheld. However, I want to stress the importance that arriving at a different final model does not necessarily question the validity of the original model.

The goal was not to create a generally applicable model but provide practitioner guidelines to reshape B2B-Business Development processes.

While the original model illustrates the process of developing new business, I conceive that the strength of the final model lies in better reflecting the reality by including the development of existing (previously unsuccessful business) due to different sample sizes. This explains why phase $I V$ precedes phase $I$ without changing the remaining sequence.

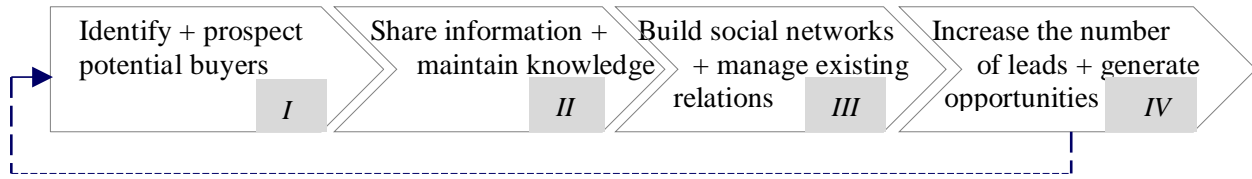

Figure 3. Process Sequences for Developing New and Existing Business Development

The Social Media phenomenon in B2B is no longer restricted to particular regions or industries but is omnipresent. I recognized that Social Media might be instrumental in changing inefficient Business Development activities which are often not adequately aligned with Marketing and Sales efforts. I acknowledged various gaps in the literature, e.g., studies limited to particular functions, perspectives, or regions.

The meaningfulness of the findings revealed that the scope of previous isolated B2B-marketing or sales studies was extended by acknowledging the bridging liaison of B2B-Business Development, and uniting vendors, third-parties, and buyers in 
The findings strongly supported the increasing importance of social media in business processes as illustrated below.

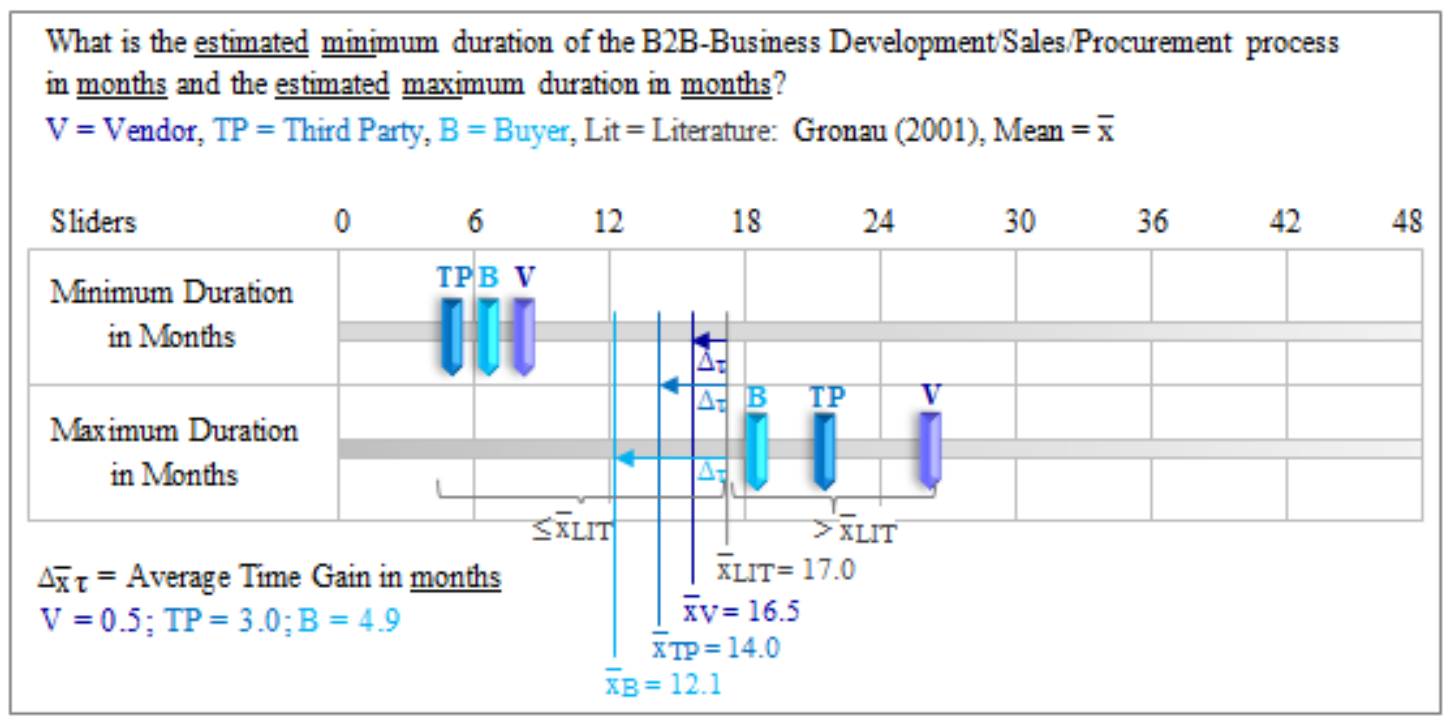

Figure 4. Average Business Process Cycle Times

Methodologically, a substantial contribution consisted of combining the disjointed areas of Social Media and B2BBusiness Development, respecting their unique methods. The suggested mixed-method approach ensured academic rigor, practical relevance, and applicability.

To go beyond, I presented a different kind of classification for Social Media Business Usage centered on frequency and intensity (Inclination and Hesitation).

Moreover, I changed the direction of the Performance discussion by blending deterministic (efficiency and effectiveness) and probabilistic (social media justification) measurements.

In today's inundation of surveys, I was attentive to engage the audience through updates and thank-you notes continuously. This creative data collection approach ensured 530+ questionnaires within six weeks and their commitment to future projects.

Managerially, the significant contributions consisted of providing strategic recommendations and guidelines.

The uncertainty about platforms in B2B-Business Development made me realize that only a minority has recognized the potential of Social Media. Raising awareness necessitated besides defining the B2B-Business Development process phases vital to the global software environment, selecting these platforms which most likely optimize Performance. I offered evidence that Social Networking Sites without Facebook, Blogs, and Microblogs are the essential platforms accelerating especially the upstream phases $I$ and $I I$ of the Business Development process. In contrast, the downstream phases $I I I$ and $I V$ fundamentally impact Performance.

Though the relevant set is not definitive, it is vital for creating the Social Business Relevance Index, a benchmark indicating which platforms are most suitable for the different phases and the overall cycle. However, it takes more than a relevant set to refocus Business Development activities and enhance performance metrics.

I took the discussion further by pointing out that a Social Business Motivation Index is critical to pulse-check the attitudes, behaviors, and drivers of Social Media Usage of the involved professionals.

The redefining of Business Development by incorporating both indices led to reflect on exchangeable criteria to define a Business Developer-typology. While old-school skeptics would rather not apply social media, cutting-edge advocates commit themselves whole-heartedly. The undecided mixed type needs guidance about potential benefits. I hope that the typology opens possibilities for aligning and enriching Business Development activities with other functions, thereby rendering processes more agile and efficient.

Therefore, managerial guidelines might update job descriptions and performance appraisals by encouraging Social Media Business Usage and analyzing the results of cutting-edge advocates versus their peers. Despite the fact, that vendors and third-parties embrace social media, a noticeable gap among buyers could be closed by providing educational work. Similarly,

Social Media alignment suggests the shift from inefficient individual and siloed activities towards coordinated efforts. Another series of interviews with C-level executives changed my perspective on Social Media Engagement. The idea behind 
different structures of decision-making layers is a region-specific content-design, for example, the Western European and North American region revealed stronger intuitive and weaker emotional values than the DACH region.

\section{Closing Remarks}

This journey was inspired by disrupting traditional B2B-Business Development practices. By leveraging Social Media, I faster generated revenue opportunities for my previous employer, a global software vendor.

The pilot study as a vantage point illuminated the previous blurry concept of Business Development among practitioners and scholars in classifying process phases vital to the global software context. This process-orientation is indeed transferrable to other B2B-settings. It stimulated awareness which social platforms, decision-makers deem vital to decision-making processes for performance initiatives.

The online survey, as a reality check, acknowledged the importance of this project: I have realized that the theoretical model grounded in literature and semi-structured interviews were mostly confirmed.

Strategic recommendations and guidelines suggest focusing on these platforms which mimic traditional media perceived by as highly reliable and useful for decision-making, for instance, Social Networking Sites as a digital option for Face-to-Face interactions.

My work makes it possible to imagine how current Social Networking Sites will eventually be reinvented. With a few mouse clicks, a small number of key decision-makers will be eligible from the vast amount of irrelevant connections based on individual background information from various data sources.

Overall, the research findings have attracted much interest among B2B-Business Developers scholars with future research concentrating on digital start-ups in the emerging regions.

\section{References}

Adler, P. S., \& Kwon, S.-W. (2002). Social Capital: Prospects for a New Concept. Academy of Management Review, 27(I), I7-40.

Agnihotri, R., Kothandaraman, P., Kashyap, R., \& Singh, R. (20I2). Bringing “social” into sales: The impact of salespeople's social media use on service behaviors and value creation. Journal of Personal Selling and Sales Management, 32(3), 333-348.

Alves, H., Fernandes, C., \& Raposo, M. (2016). Social Media Marketing: A Literature Review and Implications. Psychology \& Marketing, 33(12), I029-I038. doi:10.1002/mar.20936

Avlonitis, G. J., \& Panagopoulos, N. G. (2010). Selling and sales management: An introduction to the special section and recommendations on advancing the sales research agenda. Industrial Marketing Management, 39(7), I045-I048.

Brennan, R., \& Croft, R. (20I2). The use of social media in B2B marketing and branding: An exploratory study. Journal of Customer Behaviour, II(2), IOI-II5.

Brown, S. (20II). Social media for company research: A few of the best tools. Business Information Review, 28(3), I63-I74.

Chiu, C.-M., Hsu, M.-H., \& Wang, E. T. (2006). Understanding knowledge sharing in virtual communities: an integration of social capital and social cognitive theories. Decision Support Systems, 42(3), 1872-1888.

Colwyn, S. (20I4). The best social media platform for generating B2B leads? [Infographic]. Retrieved from http://www.smartinsights.com/social-media-marketing/linkedin-marketing/generating-leads-linkedin-infographic/

Davis, C. H., \& Sun, E. (2006). Business development capabilities in information technology SMEs in a regional economy: An exploratory study. The Journal of Technology Transfer, 3I(I), I45-I6I.

Eckhardt, J. T., \& Shane, S. A. (2003). Opportunities and entrepreneurship. Journal of Management, 29(3), 333-349.

Eidhoff, A. T., \& Poelzl, J. (20I4). Business Development: What's Behind the Name? International Journal of Economic Practices and Theories, 4(5), 835-844.

Engelen, A., Kaulfersch, A., \& Schmidt, S. (2016). The Contingent Role of Top Management's Social Capital on the Relationship between Entrepreneurial Orientation and Performance. Journal of Small Business Management, 54(3), 827-850. doi:IO.I I I I/jsbm.I2I64

Glynn, F. (2015). It takes 6 to 8 Touches to Generate a Viable Sales Lead. Here's why. Retrieved from https://www.salesforce.com/blog/2015/04/takes-6-8-touches-generate-viable-sales-lead-heres-why-gp.html

Hoffman, D. L., \& Fodor, M. (2010). Can you measure the ROI of your social media marketing? Sloan Management Review, 52(I), 4I-49.

Itani, O. S., Agnihotri, R., \& Dingus, R. (2017). Social media use in B2b sales and its impact on competitive intelligence collection and adaptive selling: Examining the role of learning orientation as an enabler. Industrial Marketing Management, 66, 64-79. doi:I0.1016/j.indmarman.2017.06.012 
Jussila, J. J., Kärkkäinen, H., \& Aramo-Immonen, H. (20I4). Social media utilization in business-to-business relationships of technology industry firms. Computers in Human Behavior, 30, 606-613. doi:http://dx.doi.org.idpproxy.reading.ac.uk/I0.1016/j.chb.2013.07.047

Kaplan, A. M., \& Haenlein, M. (20I0). Users of the world, unite! The challenges and opportunities of Social Media. Business Horizons, 53(I), 59-68.

Katona, Z., \& Sarvary, M. (20I4). Maersk Line: B2B Social Media--"It's Communication, Not Marketing". California Management Review, 56(3), I42-I56. doi:I0.I525/cmr.20I4.56.3.I42

Keinänen, H., Kuivalainen, O., \& Karjaluoto, H. (2015). Antecedents of social media B2B use in industrial marketing context: customers' view. Journal of Business \& Industrial Marketing, 30(6).

Kind, S., \& Knyphausen-Aufseß, D. Z. (2007). What Is "Business Development"? - The Case Of Biotechnology. Schmalenbach Business Review (SBR), 59(2), I76-I99.

Lee, Y. W., Strong, D. M., Kahn, B. K., \& Wang, R. Y. (2002). AIMQ: a methodology for information quality asses sment. Information \& Management, 40(2), I33-I46. doi:http://dx.doi.org/I0.I016/S0378-7206(02)00043-5

Lin, N. (2008). A Network Theory of Social Capital. The Handbook of Social Capital, 50, I-25.

McCorkindale, T., DiStaso, M. W., \& Sisco, H. F. (2013). How millennials are engaging and building relationships with organizations on Facebook. The Journal of Social Media in Society, 2(I), 67-87.

Michaelidou, N., Siamagka, N. T., \& Christodoulides, G. (20I I). Usage, barriers and measurement of social media marketing: An exploratory investigation of small and medium B2B brands. Industrial Marketing Management, 4O(7), I I53II59.

Moore, J. N., Raymond, M. A., \& Hopkins, C. D. (2015). Social Selling: A Comparison of Social Media Usage Across Process Stage, Markets, And Sales Job Functions. Journal of Marketing Theory \& Practice, 23( I), I-20.

Pöyry, E., Parvinen, P., \& McFarland, R. G. (2017). Generating leads with sequential persuasion: should sales influence tactics be consistent or complementary? Journal of Personal Selling \& Sales Management, 37(2), 89-99. doi:I0.I080/08853134.2016.1275973

Ramos, L., \& Young, G. O. (2009). The Social Technographics $\AA$ Of Business Buyers. Retrieved from http://www.rbrdatasolutions.com/ACTblog/wpcontent/uploads/2009/03/2009_forrester_social_technographics_of_business_buyers_0209.pdf

Rauniar, R., Rawski, G., Yang, J., \& Johnson, B. (20I4). Technology acceptance model (TAM) and social media usage: an empirical study on Facebook. Journal of Enterprise Information Management, 27(I), 6-30.

Rodriguez, M., Peterson, R. M., \& Ajjan, H. (20I4). CRM/Social Media Technology: Impact on Customer Orientation Process and Organizational Sales Performance. Journal of Marketing Development and Competitiveness, 8(I), 85-97.

Rodriguez, M., Peterson, R. M., \& Krishnan, V. (2012). Social Media's Influence On Business-To-Business Sales Performance. Journal of Personal Selling and Sales Management, XXXII(3), 365-378.

Rollins, M., Wei, J., \& Nickell, D. (20I4). Learning by Blogging: Understanding Salespeople's Learning Experiences on Social Media. Paper presented at the 47th Hawaii International Conference on System Science(HICSS), Waikoloa.

Royle, J., \& Laing, A. (20I4). The digital marketing skills gap: Developing a Digital Marketer Model for the communication industries. International Journal of Information Management, 34(2), 65-73.

Schultz, M., Doerr, J. E., \& Frederiksen, L. (2013). Professional services marketing: how the best firms build premier brands, thriving lead generation engines, and cultures of business development success ( $2^{\text {nd }} \mathrm{ed}$.). Hoboken, NJ: John Wiley \& Sons, Inc.

Schultz, R. J., Schwepker Jr, C. H., \& Good, D. J. (20I2). Social media usage: an investigation of B2B salespeople. American Journal of Business (Emerald Group Publishing Limited), 27(2), I74-I94.

Stephen, A. T., \& Galak, J. (2012). The effects of traditional and social earned media on sales: A study of a microlending marketplace. Journal of Marketing Research, 49(5), 624-639.

Taken Smith, K., Blazovich, J. L., \& Murphy Smith, L. (2015). Social Media Adoption By Corporations: An Examination By Platform, Industry, Size, And Financial Performance. Academy of Marketing Studies Journal, I9(2), I27-I43. 
Appendix

Table I. Framework

\begin{tabular}{|c|c|c|c|c|c|c|c|c|}
\hline \multirow{3}{*}{$\begin{array}{c}\text { Literature } \\
\text { Review } \\
\text { Job Description } \\
\text { Pilot Study }\end{array}$} & \multicolumn{8}{|c|}{ Main Constituents } \\
\hline & \multirow[b]{2}{*}{$\begin{array}{l}\text { Social Media } \\
\text { Business Usage }\end{array}$} & \multicolumn{4}{|c|}{ B2B-Business Development Process Phases } & \multirow[b]{2}{*}{ Social Capital } & \multirow[b]{2}{*}{ Usage Criteria } & \multirow[b]{2}{*}{ Performance } \\
\hline & & $\begin{array}{l}\text { Identify }+ \text { prospect } \\
\text { potential buyers }\end{array}$ & $\begin{array}{l}\text { Share information }+ \\
\text { maintain knowledge }\end{array}$ & $\begin{array}{c}\text { Build social networks }+ \\
\text { manage existing } \\
\text { relations }\end{array}$ & $\begin{array}{c}\text { Increase number of leads } \\
\quad+\text { opportunities }\end{array}$ & & & \\
\hline Discipline & Info. Technology & \multicolumn{4}{|c|}{ Entrepreneurship and Innovation; Relationship Marketing; Sales } & \multicolumn{2}{|c|}{ Social Capital; Usage; Technology } & Qual./Quantitative \\
\hline $\begin{array}{l}\text { Underpinning } \\
\text { Concepts } \\
\text { Theories } \\
\text { (References of } \\
\text { the thesis are not } \\
\text { listed in this } \\
\text { version) }\end{array}$ & $\begin{array}{l}\text { - Task-Technology/ } \\
\text { Media } \\
\text { - Media Richness } \\
\text { - Technology Usage } \\
\text { - IS Effectiveness } \\
\text { - IT Usage (Stress/ } \\
\text { Addiction) }\end{array}$ & $\begin{array}{l}\text { - Disinhibition } \\
\text { - The Strength-of- } \\
\text { Weak-Ties } \\
\text { - Relationship } \\
\text { Marketing } \\
\text { - Privacy } \\
\text { - Self-Disclosure } \\
\text { - Online Trust }\end{array}$ & $\begin{array}{l}\text { - Social Ties } \\
\text { - Trust } \\
\text { - Mutual Values } \\
\text { - Reasoned Action } \\
\text { - Information } \\
\text { Quality } \\
\text { - Tacit Knowledge } \\
\text { - Social Capital }\end{array}$ & $\begin{array}{l}\text { - Relationship } \\
\text { Marketing } \\
\text { - Marketing + Sales } \\
\text { - Trust + Reputation } \\
\text { - Social Capital } \\
\text { - Social Exchange } \\
\text { - Social Networks }\end{array}$ & $\begin{array}{l}\text { - } \text { Commitment } \\
\text { Trust } \\
\text { - Opportunity } \\
\text { - Innovation } \\
\text { - Entrepreneurship } \\
\text { - SocMed Marketing } \\
\text { - Sales } \\
\text { - Social Capital }\end{array}$ & $\begin{array}{l}\text { - Social Capital } \\
\text { - Social } \\
\text { Exchange } \\
\text { - Social } \\
\text { Network }\end{array}$ & $\begin{array}{l}\text { - Gender } \\
\text { - Generation } \\
\text { - Career } \\
\text { - Usability } \\
\text { - Playfulness } \\
\text { - Tech Services } \\
\text { - Satisfaction } \\
\text { - Usage Intensity }\end{array}$ & $\begin{array}{l}\text { - Efficiency } \\
\text { - Effectiveness } \\
\text { - ROI } \\
\text { - ROR } \\
\text { - Value } \\
\text { Co-Creation } \\
\text { - Relationship } \\
\text { Quality }\end{array}$ \\
\hline $\begin{array}{c}\text { Identified Gaps } \\
\text { in the } \\
\text { Literature }\end{array}$ & $\begin{array}{l}\text { - Current BD } \\
\text { research ignores } \\
\text { Social Media. } \\
\text { - Distilling a relevant } \\
\text { set of platforms is } \\
\text { new. }\end{array}$ & $\begin{array}{l}\text { There is no } \\
\text { agreement on a } \\
\text { precise definition } \\
\text { of the BD function } \\
\text { in } \\
\text { B2B. }\end{array}$ & $\begin{array}{l}\text { - BD Process phases } \\
\text { critical to the } \\
\text { global software } \\
\text { industry have not } \\
\text { been defined. }\end{array}$ & $\begin{array}{l}\text { - Isolated studies of } \\
\text { Marketing }+ \text { Sales } \\
\text { overlook the } \mathrm{BD} \\
\text { liaison. }\end{array}$ & $\begin{array}{l}\text { - Transfer of the } \\
\text { entrepreneurial } \\
\text { opportunity concept } \\
\text { into the corporate } \\
\text { setting is unique. }\end{array}$ & $\begin{array}{l}\text { - Both concepts } \\
\text { are novel in } \\
\text { B2B. }\end{array}$ & $\begin{array}{l}\text { - Generation } \\
\text { research for } \\
\text { Usage Criteria is } \\
\text { seminal. }\end{array}$ & $\begin{array}{l}\text { - There is a } \\
\text { lack of clarity } \\
\text { about Social } \\
\text { Media measures } \\
\text { + their impact on } \\
\text { Performance. }\end{array}$ \\
\hline Practitioner & - Strongly associated & - Yes, recognized. & - Not really & - Yes, recognized. & - Yes, recognized. & - Yes, & - Yes, & - Yes, suggested. \\
\hline $\begin{array}{l}\text { Support } \\
\text { (Central } \\
\text { Themes) }\end{array}$ & $\begin{array}{l}\text { with Linkedln, } \\
\text { Blogs, + Twitter. } \\
\text { - Sporadically with } \\
\text { Facebook + } \\
\text { YouTube. }\end{array}$ & $\begin{array}{l}\text { - Sometimes referred } \\
\text { to as 'building } \\
\text { rapport } \\
\text { connecting.' }\end{array}$ & $\begin{array}{l}\text { recognized. } \\
\text { - Referred to it } \\
\text { as 'Listening to, } \\
\text { Researching, or } \\
\text { educating } \\
\text { customers.' }\end{array}$ & $\begin{array}{l}\text { - With a strong } \\
\text { emphasis on 'trust.' }\end{array}$ & $\begin{array}{l}\text { - Sometimes referred to } \\
\text { it as 'closing } \\
\text { opportunities' or } \\
\text { 'asking for business.' }\end{array}$ & $\begin{array}{l}\text { recognized. } \\
\text { - Minority } \\
\text { confused this } \\
\text { concept } \\
\text { with privacy } \\
\text { issues. }\end{array}$ & $\begin{array}{l}\text { recognized. } \\
\text { - Associated with } \\
\text { sociodemo- } \\
\text { graphics }+ \\
\text { - technical } \\
\text { savviness. }\end{array}$ & $\begin{array}{l}\text { - Majority referred to } \\
\text { it as 'network } \\
\text { strength.' } \\
\text { - Minority required } \\
\text { quantitative } \\
\text { metrics. }\end{array}$ \\
\hline Model & Antecedent & & Indepen & ent Variable & & Moderat & or Mediator & Dependent Variable \\
\hline
\end{tabular}


Table 2. Social Media in B2B-Business Development

Literature Review

Pilot Study

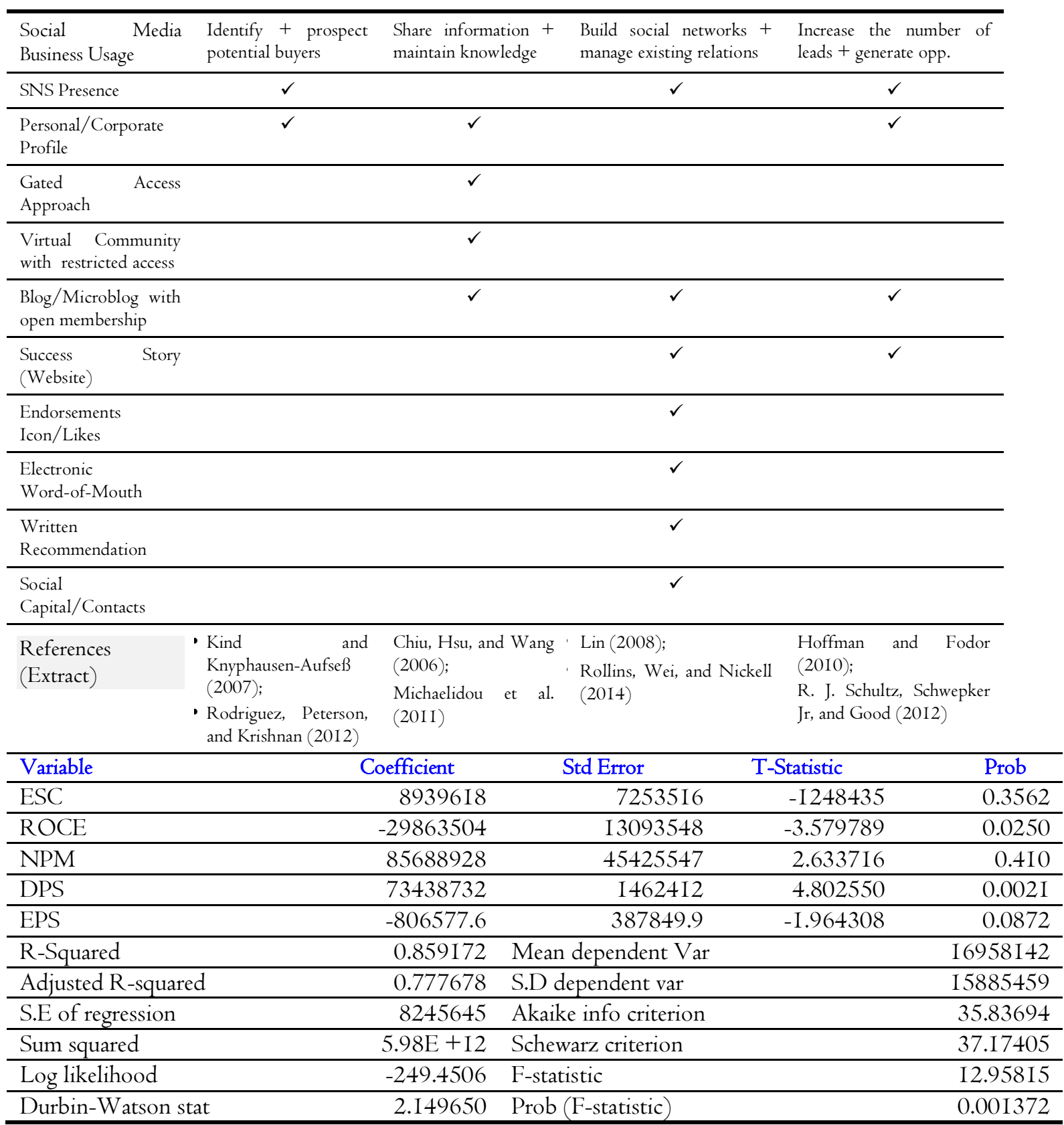

Table 3. Measurement Scales (Antecedent)

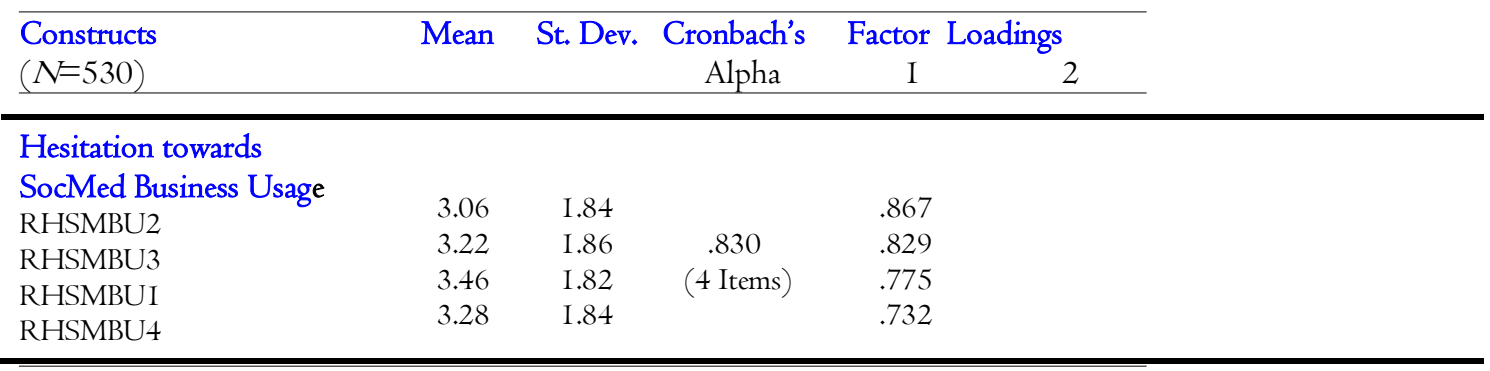


Inclination towards

SocMed Business Usage

ISMBU3

ISMBU2

ISMBU4

ISMBU5

$\begin{array}{cccc}4.02 & 2.13 & & .797 \\ 4.52 & 2.15 & .739 & .751 \\ 3.29 & 2.10 & \text { (4 Items) } & .743 \\ 4.72 & 2.04 & & .643\end{array}$

Exploratory Factor Analysis, VARIMAX Rotation, 0.5 Factor Loading-Criteria

\section{Copyrights}

Copyright for this article is retained by the author(s), with first publication rights granted to the journal. This is an openaccess article distributed under the terms and conditions of the Creative Commons Attribution license (http://creativecommons.org/licenses/by/4.0/). 